\title{
PERFORMA AYAM KUB FASE STARTER YANG DIBERI PAKAN TAMBAHAN TEPUNG DAUN KESUM (Polygonum minus Huds)
}

\author{
The Effect of Kesum Leaf (Polygonum minus huds) on Growth Performance of \\ KUB Chicken at Starter Phase \\ Wahidin Yoga Febriyanto ${ }^{1)}$, Retno Budi Lestari ${ }^{1)}$, Yuli Arif Tribudi ${ }^{1)}$ \\ 1) Program Studi Peternakan Fakultas Pertanian Universitas Tanjungpura, Bansir Laut, Kec. Pontianak \\ Tenggara, Kota Pontianak, Kalimantan Barat, Indonesia 78115 \\ Email: yuliariftribudi@gmail.com
}

\begin{abstract}
ABSTRAK
Penambahan tepung daun Kesum (Polygonum minus Huds) dalam pakan bertujuan sebagai pakan tambahan yang diharapkan mampu meningkatkan performan ayam KUB fase stater. Ternak yang digunakan dalam penelitian ini adalah 100 ekor ayam KUB dan dibagi untuk 5 perlakuan dan setiap perlakuan terdiri dari 5 ulangan. Penelitian terdiri dari 5 macam perlakuan pakan yaitu pakan komersial $(\mathrm{P} 0)$, pakan komersial $+1 \%$ tepung daun kesum $(\mathrm{P} 1)$, pakan komersial $+2 \%$ tepung daun kesum $(\mathrm{P} 2)$, pakan komersial $+3 \%$ tepung daun kesum (P3), dan pakan komersial $+4 \%$ tepung daun kesum (P4). Peubah yang diamati adalah konsumsi pakan, bobot badan, pertambahan bobot badan dan konversi pakan. Data yang diperoleh dianalisis dengan menggunakan analisis ragam (ANOVA) dan uji Duncan. Hasil penelitian menunjukkan pemberian perlakuan tepung daun kesum memberikan pengaruh terhadap performa ayam KUB fase starter. Pemberian tepung daun kesum sebesar $2 \%$ pada pakan memberikan hasil terbaik terhadap konsumsi pakan, bobot badan, pertambahan bobot badan dan konversi pakan pada ayam KUB fase starter dengan rataan sebesar 850,40 $\pm 77,13$

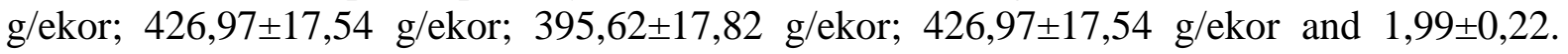
Disarankan pemberian tepung serai kesum pada pakan ayam KUB sebanyak $1 \%$ dari jumlah pakan.
\end{abstract}

Kata kunci: Ayam KUB, starter, performa, kesum

How to Cite:

Febriyanto, W. Y., Lestari, R. B., \& Tribudi, Y. A. (2021). Performa Ayam Kub Fase Starter yang Diberi Pakan Tambahan Tepung Daun Kesum (polygonum minus huds). Jurnal Nutrisi Ternak Tropis 4 (2) 124129
*Corresponding author:

Yuli Arif Tribudi

Email: yuliariftribudi@gmail.com

Program Studi Peternakan Fakultas Pertanian Universitas Tanjungpura, Bansir Laut, Kec. Pontianak Tenggara, Kota Pontianak, Kalimantan Barat, Indonesia 78115 


\section{ABSTRACT}

Addition of Kesum meal (Polygonum minus Huds) in chicken diet purposed as feed additive that expectable to support good performance of KUB chicken. The livestock that used in this research were $100 \mathrm{KUB}$ chickens, distributed for 5 treatments and each treatment comprised 5 repetitions. Diet treatments there were used in this research: feed commercial $(P 0)$, feed commercial $+1 \%$ kesum meal (P1), feed commercial $+2 \%$ kesum meal $(P 2)$, feed commercial $+3 \%$ kesum meal (P3) and feed commercial $+4 \%$ kesum meal (P4). The observation data tested by analysis of variance (ANOVA) and Duncan test. The result showed that the addition kesum powder at $2 \%$ in KUB chickens of starter period show significant effect to feed gain ration. Body weight respectively are $850.40 \pm 77.13 \mathrm{~g} / \mathrm{birdr} ; 426.97 \pm 17.54 \mathrm{~g} / \mathrm{bird}$; $395.62 \pm 17.82 \mathrm{~g} / \mathrm{ekor} ; 426.97 \pm 17.54 \mathrm{~g} / \mathrm{ekor}$ and $1.99 \pm 0.22$. Advised to do recommended kesum meal in the feed of KUB chickens as much as $2 \%$ of the total feed.

Keywords: KUB chickens, starter, performance, kesum

\section{PENDAHULUAN}

Berdasarkan PP No. 68 Tahun 2002 ketahanan pangan nasional ditekankan pada kemandirian dalam penyediaan pangan dengan memanfaatkan potensi sumber daya lokal (Haryuni dkk., 2019). Kebutuhan daging ayam lokal dalam skala nasional saat ini hanya dapat terpenuhi sebesar $30 \%$. Hal ini memberikan peluang besar untuk pengembangan usaha ayam KUB (Mayora et al., 2018). Peternak menggunakan berbagai pakan tambahan, pakan suplemen, dan antibiotik sintetik untuk mengatisipasi menghadapi kerentanan terhadap penyakit yang sering menyerang unggas. Penggunaan berbagai pakan tambahan, pakan suplemen, dan antibiotik dalam pakan.

Ternak bertujuan meningkatkan imunitas ternak, menekan populasi bakteri patogen dalam saluran pencernaan, juga digunakan sebagai pemicu pertumbuhan (antibiotics growth promoter"s/ AGP) (Sjofjan et al., 2021; Castanon, 2007), sehingga diperlukan suplemen dan antibiotik yang tidak menimbulkan resistensi. Berbagai penelitian menggunakan tanaman atau obat herbal sudah banyak dilakukan untuk menggantikan suplemen dan antibiotik sintetik tersebut. Tanaman kesum (Polygonum minus Huds) dikenal secara luas oleh masyarakat Kalimantan Barat serta merupakan salah satu kekayaan hayati yang potensial. Tanaman kesum (Polygonum minus Huds) termasuk tanaman yang mudah di jumpai di lingkungan sekitar dan banyak di jual di pasaran dengan harga yang terjangkau (Wibowo et al., 2009). Daun kesum banyak mengandung antioksidan yang bermanfaat bagi kesehatan salah satunya kandungan senyawa flavonoid (Huda-Faujan et al, 2007).

\section{MATERI DAN METODE}

Ternak yang digunakan adalah DOC ayam KUB yang diperoleh dari PT. Jatinom Unggas Perkasa sebanyak 100 ekor dengan berat badan rata-rata 31,16 g. Ayam KUB dipelihara dalam kandang battery yang terbagi menjadi 25 kotak dimana setiap kandang berisi 4 ekor ayam. Kandang yang digunakan terbuat dari kawat dan kayu.

Pakan yang digunakan adalah pakan komersial BP11-Bravo produksi PT Charoen Pokphand serta tepung daun kesum. Pakan dibagi menjadi 5 macam perlakuan yang terdiri dari pakan komersial (P0), pakan komersial+1\% tepung daun kesum (P1), pakan komersial $+2 \%$ tepung daun kesum (P2), pakan komersial $+3 \%$ tepung daun kesum (P3) dan pakan komersial $+3 \%$ serbuk pinang (P4). Kandungan nutrisi pakan komersial disajikan pada Tabel 1. 
Tabel 1: Komposisi Nutrisi Ransum Ayam Broiler Merek BP 11- Bravo.

\begin{tabular}{lll}
\hline Kadar Nutrien & Kandungan Nutrisi & \\
\hline Kadar air (\%) & Max & 13,0 \\
Protein Kasar (\%) & & $21,5-23,8$ \\
Lemak Kasar (\%) & Min & 5,0 \\
Serat Kasar (\%) & Max & 5,0 \\
Abu (\%) & Max & 7,0 \\
Kalsium (\%) & Min & 0,9 \\
Fosfor (\%) & Min & 0,6 \\
Energi Metabolis (EM) $($ Kkal/kg) & & $3,000-3,100$ \\
\hline
\end{tabular}

Sumber : PT. Charoen Pokphand, 2021

Proses pembuatan tepung daun kesum dilakukan dengan cara penepungan. Daun dipilih kemudian dibersihkan. Kemudian dilayukan dalam waktu dua hari, kemudian dikeringkan dalam oven $60^{\circ} \mathrm{C}$ selama 24 jam kemudian di giling hingga partikel terkecil. Kandungan total flavonoid pada daun kesum berdasarkan hasil analisis Laboratorium Sentral Ilmu Hayati Universitas Brawijaya adalah sebesar $19475,13 \mathrm{mg} / \mathrm{kg}(1,95 \%)$ dan aktivitas antioksidan dengan nilai IC50 sebesar 113,953 ppm. Analisis pakan menggunakan metode analisis proksimat (Adli and Sjofjan, 2018; Sjofjan et al., 2020).Peubah yang diamati adalah konsumsi pakan, bobot badan akhir, pertambahan bobot badan dan konversi pakan. Data ditabulasi dan dianalisa menggunakan rancangan acak lengkap dengan lima perlakuan dan lima ulangan menggunakan perangkat lunak, kemudian data di tabulasi menggunakan uji jarak berganda Duncan (Tribudi dan Prihandini, 2020).

\section{HASIL DAN PEMBAHASAN}

Hasil pengamatan pada Tabel 2 menunjukan bahwa konsumsi pakan ayam KUB semakin menurun dengan semakin meningkatnya penambahan daun kesum dalam pakan. Konsumsi pakan ayam KUB selama periode starter tertinggi terdapat pada perlakuan P0 sebesar $895,75 \pm 46,53$ g/ekor dan konsumsi terendah pada perlakuan P3 sebanyak 795,50 $\pm 39,47$ gram/ekor. Menurunnya konsumsi pakan pada perlakuan penambahan tepung daun kesum karena daun kesum mengandung flavonoid yang tinggi. Penurunanan konsumsi pakan seiring dengan meningkatnya pemberian tepung daun kesum, sehingga kandungan flavonoid dalam pakan juga meningkat. Keberadaan senyawa fitoestrogen (flavonoid) dan steroid dapat memicu sintesis hormon estrogen eksogenius dan endogenius dengan kuat pada usia ayam masih tumbuh (Junjian et al., 2009).

Tabel 2. Pengaruh perlakuan terhadap konsumsi pakan, bobot badan, pertambahan berat badan dan konversi pakan pada ayam KUB fase starter

\begin{tabular}{ccccc}
\hline Perlakuan & $\begin{array}{c}\text { Konsumsi Pakan } \\
(\mathrm{g} / \mathrm{ekor})\end{array}$ & $\begin{array}{c}\text { Bobot Badan } \\
(\mathrm{g})\end{array}$ & $\begin{array}{c}\text { PBB } \\
(\mathrm{g} / \mathrm{ekor})\end{array}$ & Konversi Pakan \\
\hline P0 & $895,75 \pm 46,53^{\mathrm{b}}$ & $379,62 \pm 16,38^{\mathrm{a}}$ & $352,73 \pm 23,35^{\mathrm{a}}$ & $2,37 \pm 0,20^{\mathrm{b}}$ \\
P1 & $864,38 \pm 70,66^{\mathrm{ab}}$ & $418,50 \pm 19,10^{\mathrm{b}}$ & $387,90 \pm 19,20^{\mathrm{c}}$ & $2,07 \pm 0,12^{\mathrm{a}}$ \\
P2 & $850,40 \pm 77,13^{\mathrm{ab}}$ & $426,97 \pm 17,54^{\mathrm{b}}$ & $395,62 \pm 17,83^{\mathrm{c}}$ & $1,99 \pm 0,22^{\mathrm{a}}$ \\
P3 & $795,50 \pm 39,47^{\mathrm{a}}$ & $388,20 \pm 19,17^{\mathrm{a}}$ & $357,50 \pm 18,99^{\mathrm{ab}}$ & $2,05 \pm 0,13^{\mathrm{a}}$ \\
P4 & $826,27 \pm 64,90^{\mathrm{ab}}$ & $411,72 \pm 13,64^{\mathrm{b}}$ & $380,52 \pm 13,56^{\mathrm{bc}}$ & $2,10 \pm 0,20^{\mathrm{a}}$ \\
\hline
\end{tabular}

Keterangan : Notasi yang berbeda pada kolom yang sama menunjukkan perbedaan yang sangat nyata $(\mathrm{P}<0,01)$ 
Hasil pengamatan menunjukan semakin tinggi penambahan tepung daun kesum dalam pakan akan semakin meningkatkan bobot badan dan pertambahan bobot badan ayam KUB yang dipelihara pada fase starter dimana bobot badan tertinggi terdapat pada perlakuan P2 dengan penambahan tepung daun kesum sebanyak $2 \% \quad(426,97 \pm 17,54$ g/ekor). Pemberian tepung daun kesum cenderung meningkatkan bobot badan dibandingkan kontrol. Tampaknya peran senyawa aktif yang terdapat dalam daun kesum tersebut memiliki potensi dalam peningkatan pertumbuhan Hal ini mengindikasikan bahwa pemberian tepun daun kesum dalam pakan mampu diabsorbsi dan secara aktif meningkatkan metabolisme tubuh. Bioaktif flavonoid dalam daun kesum dapat meningkatkan ekspresi insulin-like growth factor (IGF1) yang berperan sebagai mediator dalam proliferasi fibroblas dan sintesis kolagen, sehingga memicu pertumbuhan masa otot (Ouyang et al., (2016). Penambahan tepug daun kesum dalam pakan diduga adanya peran dari senyawa aktif yang terkandung di dalam daun kesum. Daun kesum mengandung flavonoid dan senyawa poly unsaturated fatty acids (PUFA) yang mampu merangsang hormon pertumbuhan. Senyawa PUFA merupakan prekursor dalam biosintesis senyawa eicosanoids, diantaranya adalah prostaglandin (Lemmens dan Bunyapraphatsara 2003). Keberadaan senyawa ini diperkirakan mampu memacu pertumbuhan sel dan dapat meningkatkan bobot badan ternak (Suprayogi et al. 2015).

Pertambahan bobot badan paling tinggi diperoleh pada perlakuan P2 $(395,62 \pm 17,83$ g/ekor) dengan pemberian tepung daun kesum sebanyak $2 \%$ pada pakan. Tingginya pertambahan bobot badan KUB yang mendapat perlakuan terbanyak disebabkan dalam daun kesum mengandung mengandung saponin, flavanoid, polifenol, alkaloid dan minyak atsiri. Menurut Lee et al (2004) minyak atsiri dapat meningkatkan pertambahan bobot badan dan berfungsi sebagai daya anti bakteri terutama pada saluran pencernaan sehigga meningkatkan pertumbuhan. Penggunaan daun kesum pada perlakuan P3 dan P4 menurunkan bobot badan dan pertambahan bobot badan ayam KUB fase stater. Hal ini diduga karena kandungan serat kasar yang cukup tinggi pada tepung daun kesum. Peningkatan jumlah pemberian tepung daun kesum dalam pakan juga akan diikuti dengan meningkatnya kandungan serat kasar. Binowo dkk., (2019) menyebutkan bahwa serat kasar yang tinggi dalam pakan dapat menurunkan produktivitas ternak. Santoso (2018) menambahkan pemberian tepung daun katuk dalam pakan dapat menurunkan bobot badan broiler sebab daun katuk mengandung tanin dan saponin yang dapat menggangu proses pencernaan. Ternak unggas merupakan ternak yang sensitif terhadap saponin. Saponin pada ternak unggas dapat menyebabkan peningkatan permeabilitas mukosa usus sehingga menghambat terjadinya proses penyerapan nutrisi.

Perlakuan berpengaruh secara signifikan terhadap konversi pakan ayam KUB selama pemeliharaan fase stater. Penambahan tepung daun kesum pada pakan dapat menurunkan nilai konversi pakan. Hal ini menunjukkan bahwa pemberian tepung daun kesum dalam pakan efisien ditandai dengan semakin turunnya nilai konversi. Pada penelitian ini perlakuan P2 $(1,99 \pm 0,22)$ memiiki nilai konversi pakan yang lebih rendah dari perlakuan lainya. Hal ini karena pengaruh flavonoid yang terkandung di dalam daun kesum (Sjofjan et al., 2019).

\section{KESIMPULAN}

Pemberian tepung daun kesum sebesar $2 \%$ pada mampu memberikan dampak positif pada penampilan produksi ayam KUB fase starter.

\section{DAFTAR PUSTAKA}

Adli, D. N., \& Sjofjan, O. (2018). Nutrient content evaluation of dried poultry waste urea molasses block (DPW- 
UMB) on In-vitro analysis. Sains Peternakan, 16(2), 50-53. https://doi. org/10.20961/sainspet.v16i2.21264

Adli, D. N., \& Sjofjan, O. (2020). Growth performance, serum blood biochemistry, and intestinal properties of Arbor Acres Broiler fed diets containing mannan-riched fraction (MRF) and probiotic-enhanced liquid acidifier. Buletin Peternakan, 44(2), 97-105. https://doi.org/10.21059/bule tinpeternak.v44i2.54713

Aedah, S., Djoefrie, M. B., \& Suprayitno, G. (2017). Faktor-faktor yang memengaruhi daya saing industri unggas ayam kampung (Studi Kasus PT Dwi dan Rachmat Farm, Bogor). Jurnal Manajemen Pengembangan Industri Kecil Menengah, 11(2), 173182. https://doi.org/10.29244/mikm. 11.2.173-182

Asmarasari, S. A., \& Suprijatna, E. (2002). Respon pemberian pellet kunyit (curcuma domestica) terhadap performans produksi dan efisiensi penggunaan protein ayam pedaging. Seminar Nasional Hari Pangan Sedunia XXVII, 251 - 255.

Binowo, S., Tulung, B., Londok, J. J. M. R., \& Regar, M. N. (2019). Efek pembatasan pakan dan sumber serat kasar berbeda terhadap performa ayam pedaging. ZOOTEC, 39(1), 112-121. https://doi.org/10.35792/zot .39.1.2019.23808

Castanon, J. I. (2019). History of the use of antibiotic as growth promotors in european poultry feeds feed. $J$ Poult Sci, 86, 2466-2471.

Haryuni, N., Lidyawati, A., \& Khopsoh, B. (2019). Pengaruh penambahan level vitamin e-selenium dalam pakan terhadap fertilitas dan daya tetas telur hasil persilangan ayam sentul dengan ayam ras petelur. Jurnal Ilmiah Peternakan Terpadu, 7(3), 287-292. https://doi.org/ 10.23960/jipt.v7i3.p287-292

Hidayat, C., S, I., \& Sartika, T. (2011). Respon kinerja perteluran ayam kampung unggul balitnak (kub) terhadap perlakuan protein ransum pada masa pertumbuhan. Jitv, 16(2), 83-89.

Huda-Faujan, N., Noriham, A., Norrakiah, A. S., \& Babji, A. S. (2007). Antioxidative activities of water extracts of some Malaysian herbs. ASEAN Food Journal, 14(1), 61-68.

Lee, K.-W., Everts, H., \& Beynen, A. C. (2004). Essential oils in broiler nutrition. International Journal of Poultry Science, 3(12), 738-752. https: //doi.org/10.3923/ijps.2004.738.752

Lemmens, R. H. M., \& Bunyapraphatsara. (2003). Plant Resources of South East Asia 12. medicinal and poisonous plants 3. Backhuys Publisher. https://doi.org/10.1016/S0378-8741(0 3) $=00056-4$

Lesson, S., \& Zubair, A. (2000). Digestion in Poultry 11. In Carbohydrates, Vitamin and Mineral. Departemen of animal and poultry science University of Guelph Ontsrio.

Miguel, M. G., Neves, M. A., \& Antunes, M. D. (2010). Pomegranate (Punica granatum L.): A medicinal plant with myriad biological properties - A short review. In Journal of Medicinal Plants Research (Vol. 4, Issue 25, pp. 28362847).

Mulyono, A. M. (2009). Nilai nutritif onggok terfermentasi mutan trichorderma AAI pada ayam broiler. Fakultas Pertanian, Universitas Veteran Bangun Nusantar.

Ouyang, K., Xu, M., Jiang, Y., \& Wang, W. (2016). Effects of alfalfa flavonoids on broiler performance, meat quality, and gene expression. Canadian Journal of Animal Science, 96(3), 332-341. https://doi.org/10.1139/cjas $-2015-0132$

Sinurat, A., Purwadaria, T., Togatorop, M., \& Pasaribu, T. (2003). Pemanfaatan bioaktif tanaman sebagai feed additive pada ternak unggas: pengaruh pemberian gel lidah buaya atau ekstraknya dalam ransum terhadap penampilan ayam pedaging. Jurnal 
Ilmu Ternak Dan Veteriner, 8(3), 139-145.

Sjofjan, O., Adli D.N., Sholikin, M., Jayanegara, A., \& Irawan, A. (2021). The effects of probiotics on the performance, egg quality and blood parameters of laying hens: A metaanalysis. Journal of Animal and Feed Sciences, 30(1), 11-18. https://doi. org/10.22358/jafs/133432/2021

Sjofjan, O., Adli D.N., Hanani P.K., \& Sulistiyaningrum D. (2020). The utilization of bay leaf (SyzygiumpolyanthumWalp) flour in feed on carcass quality, microflora instestine of broiler. International Journal of Engineering Technologies and Management Research, 6(11), 19. https://doi.org/10.29121/ijetmr.v6. i11.2019.458

Sjofjan, O, Adli D.N., Djunaidi, I., \& Kuncoro, K. (2020). Utilization of biogas liquid waste for starter in the fermentation of rice husk as a potential feed for poultry. Animal Production, 22(1), 24-30. https://doi.org/10.208 84/1.jap.2020.22.1.38

Suprayogi, A., Kusumorini, N., \& Arita, S. E. D. (2015). Fraksi heksan daun katuk sebagai obat untuk memperbaiki produksi susu, penampilan induk, dan anak tikus. Jurnal Veteriner, 16(1), 1-8.
Suryana, N. A., Galib, R., Ningsih, R. D., Darmawan, A., \& Sarjini. (2014). Pengkajian pertanian terpadu di lahan rawa lebak Kalimantan Selatan. In Laporan Hasil Pengkajian. BPTP Kalimantan Selatan.

Tribudi, Y., \& Prihandini, P. (2020). Posedur rancangan Percobaan untuk Bidang Peternakan. Universitas Indonesia Publishing.

Urfa, S., Indrijani, H., \& Tanwiriah, W. (2017). Model kurva pertumbuhan ayam kampung unggul balitnak ( KUB ) umur 0-12 minggu. Ilmu Ternak, 17(1), 59-66.

Wibowo, M., Anwari, M., Aulanni'am, \& Rahman, F. (2009). Skrining fitokimia fraksi metanol, dietieter dan nheksana ekstrak daun kesum. daun kesum (polygonum minus). Jurnal Penelitian Universitas Tanjungpura, 951(4), 410-411.

Windara, I. M., Tantalo, S., Nova, K., \& Sutrisna, R. (2018). Performa ayam kub (Kampung Unggul Balitnak) periode starter pada pemberian ransum dengan protein kasar yang berbeda performance of the starter on kub chicken rationing with different crude protein. In Jurnal Riset dan Inovasi Peternakan (Vol. 2, Issue 1). 